\title{
Features fostering academic and social integration in blended synchronous courses in graduate programs
}

Sawsen Lakhalº, Joséphine Mukamurera, Marie-Eve Bédard, Géraldine Heilporn and Mélodie Chauret

\author{
*Correspondence: Sawsen.lakhal@ \\ usherbrooke.ca \\ Faculty of Education, Université de \\ Sherbrooke, 2500 Boulevard de \\ I'Université, Sherbrooke, Quebec J1K \\ 2R1, Canada
}

\begin{abstract}
The purpose of this study was to examine the features that foster the academic and social integration of students enrolled in blended synchronous courses (BSC). Many studies and models have considered academic and social integration to be important determinants of student persistence and success in higher education programs and courses. In keeping with current research on blended courses that builds on models and theories developed for both online courses and face-to-face courses, we draw on Tinto's model (Tinto, Review of Educational Research 45:89-125, 1975; Tinto, Leaving college: Rethinking the causes and cures of student attrition, 1993) and those of Rovai (The Internet \& Higher Education 6:1-16, 2003) and Park (Proceedings of the 2007 Academy of Human Resource Development Annual Conference, 2007) to better define the academic and social integration of students in blended synchronous courses. To meet the study objective, a qualitative methodology was adopted. A convenience sampling technique was used in the study. The study participants were students $(n=8)$ enrolled in a graduate program in education offering only blended synchronous courses, as well as their instructors $(n=5)$. Semi-structured interviews (60-120 min in length) were selected as the data collection method. All qualitative data were analyzed using a general inductive approach (Thomas, American Journal of Evaluation 27:237-246, 2006). The results show that many features appear to promote academic and social integration, including the pedagogical strategies used. Moreover, this integration depends on the attitudes of both instructors and face-to-face students towards online students. This study highlights some challenges associated with blended synchronous courses. Further, it appears to suggest that instructors will need to work more on the inclusion of online students, and that training should be provided to assist them in this regard.
\end{abstract}

Keywords: Blended synchronous courses, Blended synchronous learning, Academic integration, Social integration, Higher education

\section{Introduction}

In the last three decades, information and communications technology (ICT) has evolved and a number of studies have reported its use in everyday life by seniors (Quan-Haase, Martin, \& Schreurs, 2016) and young people (Mihailidis, 2014) alike. Higher education institutions have also benefitted from ICT (Siemens, Gašević, \& Dawson, 2015), and distance education has been transformed accordingly. Several

(c) The Author(s). 2020 Open Access This article is distributed under the terms of the Creative Commons Attribution 4.0 International License (http://creativecommons.org/licenses/by/4.0/), which permits unrestricted use, distribution, and reproduction in any medium provided you give appropriate credit to the original author(s) and the source, provide a link to the Creative Commons license, and indicate if changes were made. 
course delivery modes have emerged, with blended courses being one of the most popular (Hill, 2012; Irvine, 2009; Siemens et al., 2015; Skrypnyk et al., 2015). The literature offers numerous definitions of a blended course, which vary in the degree to which students have to attend class sessions in person or online, whether learning tasks are done in-class or online synchronously or asynchronously, and students' degree of autonomy in choosing how or in which format they want to learn (Lakhal, Bateman, \& Bédard, 2017). There is widespread agreement that "blended education goes beyond just combining traditional and online teaching and learning (Benson et al., 2011). It involves a total redesign of traditional courses to include the use of technology for online communication, activities and delivery" (Kyei-Blankson, Godwyll, \& Nur-Awaleh, 2014, p.244). Three formats of blended courses have been identified in the literature (McGee \& Reis, 2012). In the first, and the most commonly used by higher education institutions, students attend face-to-face sessions supplemented with online asynchronous teaching and learning activities. These courses are called Blended Courses. It should be noted that several modes of this format also exist (Lakhal \& Meyer, 2019). In the second format, all teaching and learning activities occur online, some synchronously and others asynchronously. These courses are called Blended Online Courses (Power, 2008). In the third format, online students participate in class sessions synchronously with face-to-face students by means of ICT such as videoconferencing, web conferencing and virtual world. Asynchronous online activities are also planned for all students (Bower, Dalgarno, Kennedy, Lee, \& Kenney, 2015; Irvine, Code, \& Richards, 2013). These courses are commonly referred to as Blended Synchronous courses (Bower et al., 2015) although they are also given other names, such as HyFlex, Multi-access (Lakhal et al., 2017; Lakhal \& Khechine, 2016; Lakhal, Khechine, \& Pascot, 2014), Synchronous Blended or Synchronous Learning in Distributed Environments (Wang, Huang, \& Quek, 2018), and Simultaneous Bimodality (Collin, Calonne, Peters, Lefrançois, \& Saint-Jean, 2016). It is worth mentioning that in some of the studies reviewed, online students participated from two fixed sites, one face-to-face and the other remote, while in others, online students participated from multiple sites, in addition to the face-to-face site. These latter studies are limited in number. In this study, the focus is on Blended Synchronous Courses (BSC) in which online students are distributed across multiple sites.

BSC is gaining popularity in higher education institutions to achieve different ends. First, they improve remote students' access to higher education (Hastie, Hung, Chen, \& Kinshuk, 2010), especially in large countries such as Canada (Collin et al., 2016; Lakhal et al., 2017), Australia (Bower et al., 2015; Cunningham, 2014) and China (Szeto, 2014; Szeto \& Cheng, 2016; Wang \& Huang, 2018; Wang et al., 2018), where distances between students and higher education institutions can be considerable. It diminishes remote students' sense of isolation and allows them to get to know other students much better than if they were enrolled in an asynchronous online course (Cunningham, 2014). Also, such courses meet the demands of students who desire flexibility in their course attendance, especially adult students (Abdelmalak \& Parra, 2016; Wang et al., 2018). These students would not attend face-to-face courses, because of family and/or work responsibilities. Finally, they significantly lower educational costs for students and for higher education institutions. Indeed, these students can now benefit from contact with the instructor and the other students without needing to travel to attend face-toface sessions. Moreover, these courses have financial benefits for higher education 
institutions since some students no longer have to meet in a physical location for each class session (Butz, Stupnisky, Peterson, \& Majerus, 2014).

Given that BSC involve two kinds of students, remote and face-to-face, the aim of this study is to examine the features that foster all students' academic and social integration in BSC. Academic and social integration have been considered by many studies and models as important determinants of student persistence and success in higher education programs and courses. In keeping with current research on blended courses that builds on models and theories developed for both face-to-face courses and online courses (Skrypnyk et al., 2015), we draw on Tinto's model (Tinto, 1975, 1993) and those of Park (2007), Park and Choi (2009) and Rovai (2003) to better define the academic and social integration of students in BSC.

\section{Literature review on blended synchronous courses}

The empirical and theoretical research on blended learning is very abundant and has also been the subject of several literature reviews, systemic literature reviews and metaanalyses (e.g., Bernard, Borokhovski, Schmid, Tamim, \& Abrami, 2014; Boelens, De Wever, \& Voet, 2017; Drysdale, Graham, Spring, \& Halverson, 2013; Halverson, Graham, Spring, Drysdale, \& Henrie, 2014). However, little research has been done on BSC (Szeto \& Cheng, 2016), despite its gain in popularity. Moreover, this research is somewhat sparse (Bower et al., 2015) and exploratory in nature. Despite this, we were able to group previous research into three categories: 1) BSC design (Bower et al., 2015; Bower, Kenney, Dalgarno, Lee, \& Kennedy, 2014; Cunningham, 2014; Hastie et al., 2010; Wang \& Huang, 2018); 2) Evaluation of BSC as a delivery mode (Abdelmalak \& Parra, 2016; Butz et al., 2014; Collin et al., 2016; Kyei-Blankson et al., 2014; Lakhal et al., 2014; Szeto \& Cheng, 2016; Wang et al., 2018); and 3) Videoconferencing in BSC (Khechine, Lakhal, \& Pascot, 2014; Lakhal \& Khechine, 2016, 2017; Lakhal, Khechine, \& Pascot, 2013; Szeto, 2014). As the literature review shows, only seven studies have been performed to evaluate BSC. Additionally, given that this mode involves online and face-to-face students, it is not yet clear whether it ensures the academic and social integration of all students (Park, 2007; Park \& Choi, 2009; Rovai, 2003; Tinto, 1975, 1993) and whether they are given equal opportunity for success in this delivery mode. To our knowledge, no previous researchers have guided their analysis or interpreted their results based on an academic and social integration framework. Since this course delivery mode seems to be increasingly used in many higher education institutions (Butz et al., 2014), and given the recent interest and scarce published research in BSC contexts, the results reported in this study should provide faculties and higher education administrators with additional information and guidance, based on empirical data, on the use of BSC if they wish to implement it in academic programs. Indeed, evidence-based recommendations are needed to assist them in ascertaining what works and what does not in BSC, and to guide them in designing and implementing BSC for their students (Bower et al., 2015).

\section{Conceptual framework: academic and social integration}

Tinto's model has been applied in previous studies to explain students' transition to higher education and their ability to succeed in their program. Students' degree of 
adjustment to their academic and social environment is believed to significantly influence their decision to persist or drop out in higher education.

In his longitudinal, explanatory model, Tinto $(1975,1993)$ defined six successive sequences that underlie a student's decision-making process for persisting in or dropping out from academic courses and programs: pre-entry attributes, objectives and initial commitments, experience with the university system, integration, objectives and emerging commitments and results. Students arrive at their university with pre-entry attributes. These attributes include family background, skills, abilities and prior schooling. Pre-entry attributes are related to students' initial objectives and commitments, i.e., their professional goals and future career goals, their intention to obtain a degree, their preferred choice of higher education institution and their external commitments to others outside the higher education institution, such as family, friends, and employers. Pre-entry attributes and initial objectives and commitments have an influence on students' academic and social integration. Once at the higher education institution, the student has an experience with the institution and interacts with formal and informal academic and social systems. These systems are characterized by activities involving instructors, non-teaching staff and peers, and include interactions with these individuals in formal settings (courses, assignments, content, teaching, learning and assessment activities, supervision, etc.) and informal settings (breaks between classes, out of class activities, before beginning the class, etc.). During this process, students' initial objectives and commitments are adjusted according to what they have experienced in their new environment. Positive experiences with the academic and social systems strengthen students' academic and social integration and lead them to persist in their courses and programs. However, negative experiences tend to undermine academic and social integration and lead students to drop out from courses and programs. Experiences in the academic system and the social system could influence each other. Both types of integration are important in the decision to persist or to drop out from higher education (Tinto, 1975, 1993).

According to Tinto $(1975,1993)$, academic integration is defined by students' academic performance, level of intellectual development, and perception of having a positive experience in academic settings, while social integration is defined by involvement in extracurricular activities and the presence of positive relationships with peers. In this regard, in Tinto's model (Tinto, 1975, 1993), instructors play an important role in students' academic and social integration through the choices they make pertaining to course and program contents, supervision provided, teaching, learning and assessment strategies used, etc. Academic and social integration depend on the appropriateness of course and program contents, teaching and learning, and assessment strategies for students' needs. The match between on one hand students' needs, interests and preferences with regard to the various elements listed above, and on the other the higher education institution's offer of these same elements (Tinto, 1993), is key to academic and social integration.

Tinto's model was conceived for on-campus courses and programs. It does not take ICT or course delivery modes into account. The determinants of student academic and social integration in online courses and programs in higher education have been defined in some models, such as those of Park (2007), Park and Choi (2009) and Rovai (2003). These models supplemented Tinto's model (Tinto, 1975, 1993) with some 
characteristics of adult students (Bean \& Metzner, 1985) and of online courses and programs, which could influence students' experience of academic and social systems, and thus, their academic and social integration. Adult students' characteristics include financial aspects (capacities and problems), employment status, hours of employment, management support, scheduling conflicts, family responsibilities and issues, outside encouragement, opportunities for transfer, life crisis, and personal issues. Online course characteristics for their part include students' skills and computer literacy, information literacy, computer-based interactions, technology/technical usability issues and instructional design of the courses. Tinto's $(1975,1993)$ model and those of Park (2007), Park and Choi (2009) and Rovai (2003) have been validated by a number of studies, mainly quantitative. These models remain relevant in the context of this qualitative study, as the aim is to examine the features that foster academic and social integration in BSC. These features should stem from the determinants of academic and social integration listed in these models. Figure 1 depicts an integrated model from Park (2007), Park and Choi (2009), Rovai (2003) and Tinto $(1975,1993)$.

More specifically, in this study, we are interested in students' experience with the university system (see Fig. 1) in regard with BSC while taking into account these courses' characteristics. Students' satisfaction with their experience in BSC strengthen their academic and social integration and lead them to persist in their courses and programs. The research questions were stated as follows:

1) What are the instructional strategies (teaching, learning and assessment strategies) more suited in order to ensure students' satisfaction (online and face-to-face) and therefore their academic and social integration in BSC?

2) What are the skills and attitudes of instructors and students that increase (or decrease) satisfaction and facilitate (or hinder) the academic and social integration of all students (online and face-to-face) in BSC?

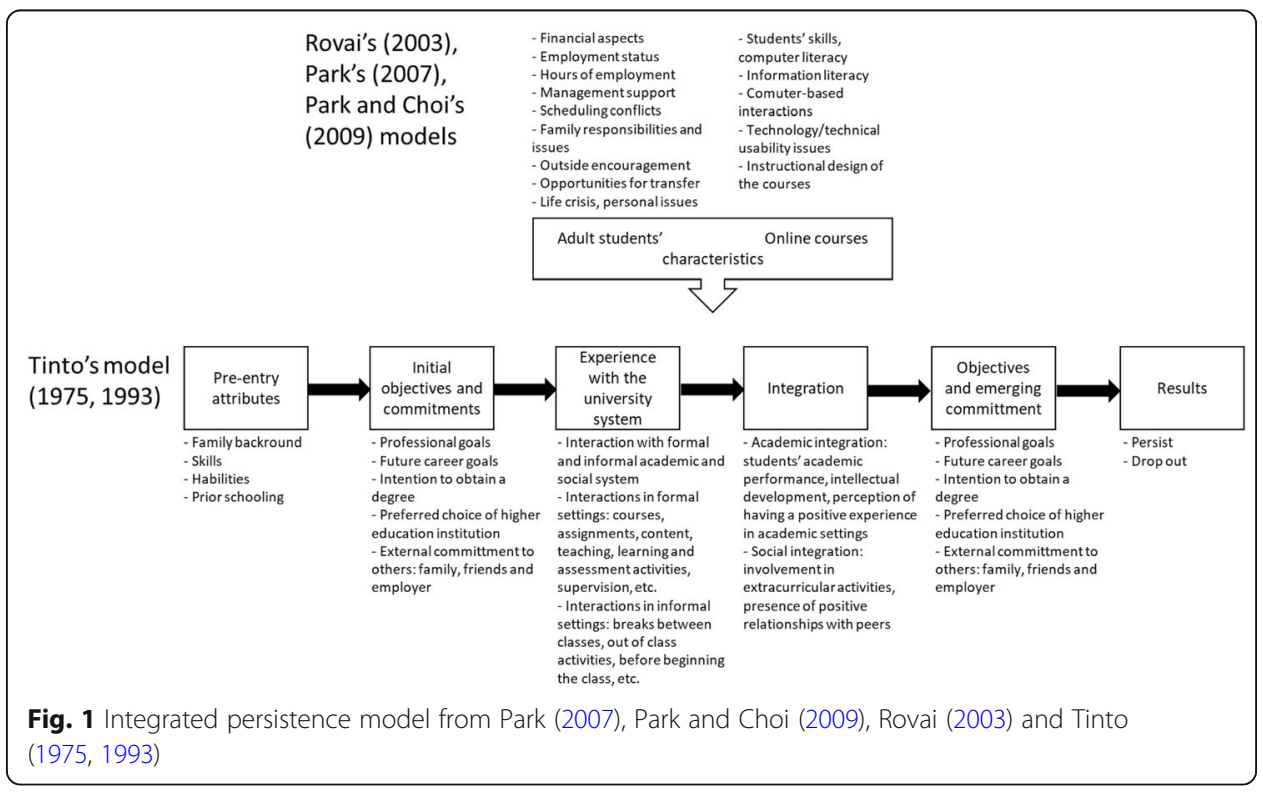




\section{Methodology \\ Context of the study}

The study was conducted with instructors and students enrolled in the Master Teacher Program (MTP) at Université de Sherbrooke (Canada). The MTP is a program designed to enable practitioners to develop reflective and critical thinking skills for their teaching, and to develop research expertise using methods of inquiry into the scholarship of teaching and learning. These practitioners are teachers currently working in Anglophone public and private colleges in the province of Quebec, Canada. Some of these colleges are situated in the Montreal area, others outside of this region. The MTP confers three different levels of graduate degrees: a graduate certificate in college teaching (GCCT), a graduate diploma in college teaching (GDCT) and a master's degree in college teaching (MCT). It covers educational psychology, instruction, pedagogical content knowledge, and discipline-based learning, in all cases with the aim of furthering the professional abilities and reflective practices of its teacher participants.

In an effort to serve Anglophone college teachers outside the Montreal region, BSC has been implemented in the MTP since 2006 and up to the present. This context of BSC use is different from the contexts reported in the literature by Abdelmalak and Parra (2016), Bower et al. (2015), Lakhal et al. (2014) or Wang and Huang (2018), because students have no choice about the type of course participation, as residents of the Montreal area must attend face-to-face classes, whereas remote students have to attend courses online synchronously. Desktop videoconferencing, which permits two-way communication, is deployed in each course session. Moreover, actual face-to-face session time is reduced and replaced with learning and assessment activities conducted asynchronously, and, in some courses, conducted online synchronously between class meetings. Remote students enrolled in the MCT are asked to be physically present in class at four key times during the 45-credit program in order to provide real contact with their colleagues and develop a sense of belonging to their cohort or class group.

\section{Participants}

A convenience sampling technique was used in the study. All students and course instructors in the MTP were invited by e-mail to participate in the study during the 2017 summer and fall sessions. Among these students, 35 expressed their interest in participating in the project. We then have randomly picked up 4 online and 4 face-to-face students, amongst all the students who responded positively to the invitation. As for instructors, 6 expressed their interest, but 5 have been randomly picked up for the semistructured interviews. The final sample consisted of 8 students ( 4 online and 4 face-toface) and 5 instructors agreed to participate in the semi-structured interviews. These participants were coded T1 to T5 (for instructors), SD1 to SD4 (for online students), and SP1 to SP4 (for face-to-face students). Participants were offered a \$50 incentive as compensation for their time. Table 1 outlines the demographic details of the study sample.

\section{Methods and analysis}

An exploratory case study approach, using qualitative data, was adopted for this research (Yin, 1994). Data collection was comprised of semi-structured online interviews. 
Table 1 Demographic details of the study sample

\begin{tabular}{|c|c|c|c|c|}
\hline & Characteristics & Instructors & $\begin{array}{l}\text { Online } \\
\text { students }\end{array}$ & $\begin{array}{l}\text { Face-to-face } \\
\text { students }\end{array}$ \\
\hline \multirow[t]{2}{*}{ Gender } & Male & 1 & 1 & \\
\hline & Female & 3 & 3 & 4 \\
\hline \multirow[t]{8}{*}{ Age group } & $25-30$ & & 1 & \\
\hline & $30-35$ & & 1 & 1 \\
\hline & $35-40$ & & & \\
\hline & $40-45$ & & 2 & \\
\hline & $45-50$ & 2 & & 2 \\
\hline & $50-55$ & & & \\
\hline & $55-60$ & & & 1 \\
\hline & $60-65$ & 2 & & \\
\hline \multirow{2}{*}{$\begin{array}{l}\text { Number of years of teaching in the MTP } \\
\text { (for instructors) }\end{array}$} & $0-5$ & 3 & 2 & \\
\hline & $5-10$ & & 2 & 2 \\
\hline \multirow{2}{*}{$\begin{array}{l}\text { Number of years of teaching at the college } \\
\text { level (for students) }\end{array}$} & $10-15$ & 1 & & 1 \\
\hline & $15-20$ & & & 1 \\
\hline Number of BSC taught (for instructors) & $0-5$ & & & 2 \\
\hline \multirow[t]{3}{*}{ Number of BSC enrolled in (for students) } & $5-10$ & 3 & 1 & \\
\hline & $10-15$ & 1 & 1 & 2 \\
\hline & $15-20$ & & 2 & \\
\hline \multirow[t]{3}{*}{ Level of computer skills } & Average & & 1 & 1 \\
\hline & Good & 1 & & 1 \\
\hline & Very good & 3 & 3 & 2 \\
\hline
\end{tabular}

Given that the principal researcher was also the director of the MTP, her research assistant was responsible for conducting the interviews and for anonymizing the data, using a code for each participant. Ethics approval was secured from the ethics review board of the university where the study took place (approval number specification CER-ESS_2017_12). All participants signed a written consent form for their participation in an individual interview video-recorded. In order to gather information relevant to our research questions, two interview guides were drawn up on the general topic of participants' experience with BSC in the MTP: one interview guide for instructors (including 3 open-ended questions) and another for online and face-to-face students (including 4 open-ended questions). The questions were worded in a general manner to allow participants to express themselves freely. Sub-questions were also asked to further explore the topic. Following demographic questions regarding gender, age, experience in both college teaching and BSC, and level of computer skills, students and instructors were asked to think and reflect on respectively the best and the worst course they were enrolled in (they taught) in the BSC mode. Sub-questions invited them to share about features (strategies, skills, attitudes, etc.) used in BSC to enhance students' satisfaction, and their academic and social integration. They have also been asked to explain why, in light of all their experiences in BSC, if they had a choice of the delivery mode, if they would enroll in another BSC again (if they would offer a BSC again). The interviews were 90 to $120 \mathrm{~min}$ long and were video-recorded using Skype software and then transcribed verbatim. All qualitative data were analyzed using a 
general inductive approach (Thomas, 2006). The data analysis method was thematic analysis (Paillé \& Mucchielli, 2016) in keeping with the six stages of Braun and Clarke (2006): transcribing data, generating initial coding, searching for themes, reviewing themes in light of the conceptual framework, naming and defining themes, and producing the report. The transcriptions were coded manually using a list of general themes corresponding to the questions and sub-questions of the interview guides. These general themes were then reviewed, in connection with the determinants of academic and social integration. A thematic analysis (Paillé \& Mucchielli, 2016) was then carried out, and a synthesis reflecting the salient ideas emerging from the transcript was produced for the purpose of this study.

\section{Results}

The results are presented in two sub-sections. These sub-sections highlight the main themes emerging from the analysis of the semi-structured interviews. The themes and the subthemes developed are presented in Table 2 and in the following paragraphs.

\section{Appropriateness of pedagogical strategies and BSC for students' training needs}

Two sub-themes emerged with regard to this theme: 1) course content, teaching, learning and assessment strategies, and 2) appropriateness of BSC for students training needs.

\section{Course content, teaching, learning and assessment strategies}

The MTP is a program designed for practicing college teachers. The teaching and learning activities deal with the various aspects of teaching work that MTP students will replicate in their own courses with their students, which is a source of motivation and engagement. In order to help students assimilate course content, instructors give concrete examples based on their own teaching experience, as a face-to-face student remarked:

They need to explain in such a way that people understand what you mean and you need to be able to maybe provide examples, tangible examples so that it becomes clear that we can kind of take that information and consolidate it (SP3).

Table 2 Results for the features fostering academic integration and social integration in BSC in the MTP

\begin{tabular}{ll}
\hline Themes & Sub-themes \\
\hline Appropriateness of pedagogical strategies and BSC & $\checkmark$ Course content, teaching, and learning and assessment \\
to students' training needs & strategies \\
& $\checkmark$ Appropriateness of BSC for student training needs \\
Attitudes, experience and skills of participants for & $\checkmark$ Instructors' and teaching assistants' experience with BSC \\
online students' inclusion & $\checkmark$ Instructors' and teaching assistants' attitude \\
& $\checkmark$ Instructors' level of technological proficiency \\
& $\checkmark$ Face-to-face students' attitude \\
& $\checkmark$ Online students' attitude and technological skills \\
\hline
\end{tabular}


The assessment strategies also help students in their daily practices, according to an instructor, because the assignment they have to do is directly related to their own teaching. This has an impact on their academic and social integration, and, thereby, their persistence in the program. In one instructor's words:

We found that it helped us in our practice. The fact that every single assignment we give them is to prepare something for one of their classes. It's not just to do something. I think that's had an impact too on them choosing to continue (T1).

In the MTP, the emphasis is much more on pedagogical approaches than on specific content, because these approaches give students a better toolbox in the end. The approaches used by some MTP instructors are directly deployed in their MTP teaching. However, this is not always the case. Some instructors do not practice what they teach themselves: "They were giving us all sorts of amazing pedagogical practices to do, and making us almost feel guilty for not using them, and then you get to see them teach, and they're not practicing what they preach" (SD1). This is also true for assessment strategies. The harsh assessments of some MTP instructors seemed inadequate to their students. Being teachers themselves, the latter were well aware of the effects of grading:

We were graded very kind of harshly in a way and I kind of felt like it was a little bit heavy handed. It was a bit unnecessary. The thing is that as teachers taking courses to improve our teaching, we're very well aware of grading and rubrics and all of that kind of stuff. Sometimes it can feel a little stern, I guess (SP3).

MTP students are less interested in theoretical content and difficult readings that are not related to their daily teaching practices. Thus, the required readings were often a source of dissatisfaction for the students, which led instructors to review their strategies:

They had been asked to read something before they came to the first class and came out the first day saying that they hated the book and why would we ever choose this alpha book and talking about. I mean it's so negative and it was first class and like, "Oh my goodness." I knew what my challenges were (T4).

\section{Appropriateness of BSC for students' training needs}

Students perceived the BSC delivery mode as the current trend in education. This is also a delivery mode that they would like to reproduce in their own classes in order to improve their accessibility. According to an online student:

I teach blended yeah. It was my first semester, it was also my first semester in the MTP and it just made me realize that there were so many options that we could 
do both to integrate online learners but also to mix them up with students in class because I have both types (SD2).

Instructors' use of BSC provides students with examples of this delivery mode to inspire their own courses. According to an online student:

The fact that the teachers were able to use the blended format so well, it was directly relevant to what we were learning. It was like they were sort of giving us examples of what we could use in our own classrooms in the future. I found that really helpful (SD3).

The use of Moodle in the BSC context gave students some examples of how to use this platform and helped them discover its interactive tools. According to a face-to-face student: "My ClassA classroom that was blended, it opened my eyes to the idea of using Moodle as a more blended learning tool, online tool, and I've taken it on for one course" (SP1). Moreover, students' ability to share experiences and resources amongst themselves during the course was also helpful because it provided them with new strategies and tools that could be reinvested in their own teaching in BSC. A face-to-face student commented on this: "You get samples from people when they do their own presentation. That was really helpful and it's going to help me in my job to develop blended" (SP4).

\section{Participants' attitudes, experience and skills pertaining to the inclusion of online students}

The inclusion of online students seems to be a major issue in BSC, and many participants commented on this aspect. The inclusion of online students depends on instructors' and teaching assistants' experience and attitude, instructors' level of technological skill, face-to-face students' attitude, and online students' attitude and level of technological proficiency.

\section{Instructors' and teaching assistants' experience with BSC}

Instructors' experience with BSC is one of the key elements of success for these courses. Indeed, having instructors with significant experience and a clear vision of the objectives to be achieved in the course helps to ensure course quality, regardless of the technologies used. According to a face-to-face student:

Well the teacher was very experienced. She had a good vision of where she wanted to go. Had she not been such a good teacher, I don't think any level of technology would have made it good, and the technology did not get in the way for sure (SP8).

In all courses of the MTP, each instructor is paired with a teaching assistant. Teaching assistants are employed to manage technology-related problems, respond to online student chat comments, and manage other issues. The qualities and qualifications of the teaching assistant also seem to be an issue in BSC. A teacher's or assistant's lack of skill 
could, conversely, be a concern for students, especially for online students. According to an online student:

My point was to get a masters (...). I knew I was going to keep going, but it made me dread sometimes when I would know that it was that teacher teaching, or that tech tech-ing for another course (SD1).

\section{Instructors' and teaching assistants' attitude}

The instructor's attitude, openness, enthusiasm and support play an important role in students' academic and social integration in BSC. According to a face-to-face student: "I think the teacher's enthusiasm was one thing and there is the technology, that helps a lot too. They were supportive" (SP4). Talking about an instructor, an online student stated: "It was really inclusive, and it felt like the teacher really cared about us and valued our point of view, and added to it too" (SD1). By encouraging online students' participation, instructors reduce the gap between online students and face-to-face students, as an online student stated: "Those that did it well, we didn't feel like we were online in a separate environment with something specific, we were just students" (SD4). And the same individual added: "If I wouldn't have that participation in this class I would probably not be in the program anymore" (SD4).

Some instructors were aware of the realities of online students and adopt attitudes to be more inclusive towards them. Examples include asking them questions directly and by name, and always facing the camera while teaching to the group:

I choose to arrange the classroom so that when I'm even when speaking to the group in front of me, I am looking at the camera. Most people have the camera on the side but I'm actually face on, on the camera (T4).

This was also reported by a face-to-face student: "There are a few classes where that person was very much involved and looking onto the person on screen, and making sure that the activity that was planned worked well with somebody else abroad" (SP1).

Another element is to consider online students first:

I always have to keep, as if ... I mean, remember you have these students that are outside, because it's so hard to disengage from the environment of the classroom, but always intentionally I go first to teach the [online] students ... (T3).

Giving them extra attention, especially when they are few, may, however, lead to some problems with face-to-face students, who can feel neglected by the instructor:

They are far, they are not there. You want to put them as much as possible. Sometimes even artificially, just to take them in and you compensate, but it's a must because there are only two out there and the class is 15 here. What do you do with that? It's a big conflict (T3). 
Moreover, from face-to-face students' point of view, interactions with online students seem somewhat disjointed because instructors have to regularly check if they want to pitch in:

That it was a little bit disjointed having to ask the people online, do you have anything to say and they had like, they would raise their hand or they'd put like smiley faces or thumbs up, whatever icons they had, but they did seem a little, it did seem a little disjointed (SP3).

A negative attitude on the part of some instructors towards online students may be a source of dissatisfaction. Some online students reported that certain instructors turned their backs to the camera, which prevented them from hearing the instructor and excluded them from the classroom. Others even celebrated the fact that they had no online students in their courses:

TeacherB, who is the guru of the project, and who really needs online students, was celebrating the fact that she didn't have online students in her course this summer. It's just the feeling that you're a burden for everybody, you know? (SD1).

Other instructors ignore or forget online students. This was confirmed by a face-toface student: "There's some teachers who as much as they want the blended learning, they do forget that there is somebody abroad out there" (SP1). These instructors either turn their backs to the camera and/or consider only face-to-face students:

She would routinely stand with her back to the camera facing away from us, so we couldn't hear her very well, we couldn't see her, and we just felt that she was completely teaching to the students in the room and just forgetting about us (SD3).

Certain instructors do not even greet online students, making the latter feel that the course is intended only for face-to-face students and leading to their disengagement: "It was really disempowering and I definitely felt myself disengaging a lot in that course" (SD1).

In some cases, neither the instructor nor the teaching assistant interact with online students, relegating them to the mere role of spectator. According to an online student:

We never really were asked a question, we never had the chance to answer, we never had a way to raise our hand to say we have something to say, so yes, in the software there's the option for it, but either the IT person or the teacher were not interacting with us. We were just seeing the classroom (SD4).

This leads to a strong sense of exclusion:

I think the best way to explain it is that I felt like a fly on the wall in the classroom. [...] either the IT person or the teacher were not interacting with us. We were just seeing the classroom (SD4). 
Including online students is a constant challenge for instructors. According to an instructor, it is easy to forget them: "I'll be honest with you, sometimes it's very easy to forget students outside. It's so easy" (T3). According to an online student, some instructors suddenly remember that online students are attending the course session, and then they ask them sporadic questions, which make them feel uncomfortable:

It happened so often with other teachers where they just forget about you, and then all of a sudden they turn around and then they ask you a question. You have nothing to say, and so it sounds like you don't participate, but you had so many things to say before (SD1).

The use of microphones and cameras in the classroom by some instructors or some teaching assistants could affect online students' integration and participation in the course. Following are some examples of this poor use of these devices. According to an online student: "Sometimes just where the mic is placed in the classroom can make a huge difference for us online learners" (SD2). Some teaching assistants stand too close to the microphone instead of turning up the volume of their speakers, causing sound problems:

I had some techs who were just so close to the microphone, but you have to turn the volume up to hear what people are saying in the class, and so they would just go ahem, and it just bursts into your ears (SD1).

Sometimes, they neglect to move the camera to allow online students to see who is speaking in the classroom, or fail to keep an eye on the screen when an online student cuts in: "When you're at a distance, you say something, and then they don't even look at you or at the screen, and then they're just like, moving on" (SD1). For all these reasons, an online student reported that the program was not ready to welcome online students: "If I would have come up with the idea that the program is not ready for the students that are online" (SD4).

\section{Instructors' level of technological proficiency}

Instructors' level of technological skill could be a source of satisfaction and motivation for online students: "Basically, the teachers teaching the course make a huge difference, and their level of comfort, and their level of familiarity with the technology" (SD3). The instructor should be familiar with ICT. This allows online students to have a good learning experience. Depending on the instructor who teaches the course and their ease with ICT, this experience can vary, according to an online student: "... but until I knew which teacher would teach the class, I didn't know if I would have the same return on investment if it was somebody that was uncomfortable with technology" (SD4). Instructors' level of technological skill may be a challenge in BSC, when they are not comfortable with the use of ICT. However, this result should take into account that some students perceive that instructors' experience is more important in BSC quality than their level of technological skill or the technologies used (see 3.2.1). 


\section{Face-to-face students' attitude}

With regard to the efforts made by face-to-face students to include online students, most of the interviewees who discussed this sub-theme were online students and instructors. According to a face-to-face student, face-to-face students must be aware that there are online students in the group who learn differently, as compared to students in regular face-to-face class sessions: "I think as online learners and people that are in class that they're aware that we have online learners. We have to consider that there are other people trying to learn differently from what we're actually learning" (SP2). In this context, online students must be included collectively, as an instructor suggested:

They want to connect with the students from a distance and it just all works well because we all collectively recognize that there's people at a distance that need to be included and that the group in class is aware of them. Each of them individually is also aware that there's these people at a distance (T4).

However, some online students complained that face-to-face students make no effort to include them, for example, by failing to greet them on camera at the beginning of the course sessions, or neglecting to switch off their microphone when they are not speaking, which creates noise that can prevent online students from hearing class discussions. Some face-to-face students were even reluctant to interact with online students in group work and chose to team up with their face-to-face classmates. An instructor mentioned on this topic: "I noticed that people in the class, sometimes during the breakout rooms, are reluctant to go out. They want to be in" (T3).

\section{Online students' attitude and technological skill}

Online students should have appropriate attitudes and technological skill. Regarding the attitudes of online students in BSC, very active participation breaks the sense of remote participation. Talking about an online classmate, a face-to-face student reported, "When she's in class with us, you feel like she's with us physically. It makes the difference. She's always making comments on everybody, and participating $100 \%$ " (SP1). However, some online students may hinder smooth classroom functioning. For example, certain online students connect late, which makes it impossible to solve their technological problems, while others fail to use the click to raise their hand, or interrupt people speaking in the classroom. This may annoy their face-to-face classmates:

For example online learners, some students don't necessarily raise their hand because we have this little click option that we can "I have a question." Some people just turn on their mic and sort of cut off the person talking in class which I don't really find respectful (SD2).

Others refuse to participate, and then pretend to feel they are not included in the class, as an instructor mentioned:

I know for a fact, and other people, like the technician that I was working with, also acknowledged that I would pause during the class and turn to the screen and 
ask the people online "Do you have anything to say, do you have any comments?" and they were silent. Nobody would answer, but then meanwhile they were chatting with the technician, saying, "We don't feel like we're being included," and the technician would say, "Well T5 just asked you a question" (T5).

All students' level of technological skill may also be a challenge for academic and social integration in BSC. Talking about some students in a particular course, an instructor reported that:

They were so afraid of technology. It was very difficult to get them to break the barrier to buy into it, of course. I'd say the biggest difficulty is always the difference in skill level. Some are very, very low, some are very high or more high (...). When you have a class of 28 , it's really difficult to have 8 people who can't help themselves (T1).

\section{Discussion}

The aim of this study was to shed light on the features that foster the academic and social integration of all students in BSC. In this study, based on the results of semistructured interviews conducted with online students, face-to-face students and instructors, a total of two themes emerged. For each of these themes, sub-themes were also identified. The discussion section is organized according to these themes.

\section{Appropriateness of pedagogical strategies and BSC for students' training needs}

According to Tinto $(1975,1993)$, instructors play an important role in the academic and social integration of students through the choices they make in regard to course and program contents, supervision provided, teaching, learning and assessment strategies used, etc. Students' academic and social integration depend on the match between their needs and the response of the higher education institution, including instructors. In this regard, Severiens and Schmidt (2009) claimed that "institutions should adapt to students and cater for their needs, in order to stimulate outcomes" (p.68). For example, this could be done by taking into account students' approaches to studying, strategies and practices used when designing curricula and assessment methods (Lane, 2016; Severiens \& Schmidt, 2009). In the context of this study, the students are practitioner college teachers, they are part-time students with specific needs (Lee, 2017). They enroll in the MTP to develop knowledge in different fields of education (educational psychology, instruction, pedagogical content knowledge, etc.) and to acquire the ability to think reflectively and critically about their teaching. These knowledge and skills should be transferable to their daily teaching with their own students as and when it is gained. The results of the study revealed that generally speaking, the teaching, learning and assessment strategies used by MTP instructors respond adequately to their students' needs, in turn strengthening the academic and social integration of students (Lane, 2016; Lee, 2017). However, some instructors do not practice what they teach, e.g., they make some assessments unnecessarily harsh, or require irrelevant or theoretical readings. In order to interpret this result, two points of view should be taken into account in a balanced way. On the one hand, these instructors need training in order 
to properly understand the philosophy behind the program. As the MTP is a continuing education program that aims to enable college teachers to become better teachers, rather than a competitive and selective teacher education program, instructors' understanding should be improved and better adapted to the circumstances. On the other hand, students require theoretical readings in order to acquire critical thinking about teaching and learning. Certain students may view such readings as useless since they may have a utilitarian relationship to their training, only accept course content directly related to their needs as teachers, and are unable to go a step further and to develop a more comprehensive view on this content. Moreover, some instructors tend to change their course content to accommodate these kinds of students, which may be a questionable response.

BSC as a delivery mode meets the students' training needs, in that some of them are reproducing it in their own teaching contexts in order to improve their courses' accessibility. By using best practices in BSC, including those pertaining to Moodle and its interactive tools, instructors give students good examples to follow in their own teaching and learning activities. In this context, instructors act as role models. Observing instructors successfully perform a task could help students perform the same task by imitation and give them confidence in their own ability to do so. In this scenario, the students view instructors as having salient features similar to their own, as they are also college teachers. This echoes the concept of vicarious experience, which is one of the four sources of self-efficacy (Bandura, 1997).

\section{Attitudes, experience and skills of participants for online students' inclusion}

According to the study participants, having experienced instructors and teaching assistants with a proper attitude towards online students is one of the key elements in BSC success and in social and academic integration. Indeed, instructors' openness, enthusiasm and support are essential features for academic and social integration, especially for online students. Some instructors adopt strategies to include them in the class discussions (e.g., always facing the camera while teaching the group, calling on online students first, or giving them extra attention). These strategies have also been uncovered by previous studies (Bower et al., 2015). However, when they are engaged in discussions with face-to-face students, other instructors ignore or forget the online students (Wang \& Huang, 2018). This contributes to a strong sense of exclusion. Online students reported that some courses are intended only for face-to-face students. These attitudes towards online students may be explained by the instructors' lack of experience with BSC courses. The fact that they are hired based on their experience delivering face-toface courses does not mean that they possess the necessary skills to be good instructors in BSC. Instructors should undergo training to develop expertise in effective BSC. They also need information and practical advice on these courses. At the university where the study took place, a teaching and learning center has been established to support instructors in developing their teaching skills in online, blended, blended synchronous and face-to-face courses. Given that the MTP instructors are from the Montreal area, they do not have the opportunity to meet instructional designers to discuss the skills required for successful BSC implementation. Another solution should be found. This, however, requires institutional commitment, time and additional resources (Moskal, 
Dziuban, \& Hartman, 2013). Moreover, instructors should also be able to assess their performance in BSC. For example, there could be a video coverage of instructors during their teaching lessons in BSC so that they will have a review of their performance and improve on specific aspects where necessary.

The cognitive overload generated by instructors' split attention between online students and face-to-face students may also explain instructors' attitudes towards online students. Managing both types of students at the same time may be difficult for instructors (Francescucci \& Foster, 2014; Hastie et al., 2010), even if a teaching assistant is paired with each instructor in BSC in the MTP. This cognitive overload was also reported by previous studies as a challenge to be addressed in this course delivery mode (Bower et al., 2014, 2015; Cunningham, 2014; Wang \& Huang, 2018). Another explanation for these negative attitudes may be instructors' difficulty gauging online students' understanding of the course content in BSC. For face-to-face students, instructors always have access to nonverbal cues and are able to determine if they understand the topics under study. However, online students' attitudes are not always accessible to instructors, especially when the former do not use a camera. It then becomes necessary to find other alternatives, for example, making the use of cameras mandatory for online students, or using alternative techniques such as quizzes or online polls as formative evaluation tools to gauge student understanding of the course content being taught (Bower et al., 2014; Francescucci \& Foster, 2014).

Instructors' level of technological proficiency facilitates online students' inclusion and enhances their academic and social integration. When instructors are comfortable with technologies, students tend to be more satisfied and motivated. However, in MTP, not all instructors possess this ease, a fact that can limit online students' inclusion in the course. The challenge of instructors' level of technological proficiency has also been reported by previous studies (Bower et al., 2014, 2015; Cunningham, 2014). It is thus important for instructors to undergo technology training in order to be able to use IT adequately, and to ensure the tools are functional and reliable. They should also test out and practice the use of the various technological tools, including communication systems, involved in BSC before the beginning of the course (Bower et al., 2014, 2015; Lakhal et al., 2017). Some training videos should be provided in this respect, in order to allow instructors to improve their IT skills.

In BSC, face-to-face students' attitudes can encourage or hinder the academic and social integration of online students. These students should be aware of the existence of online students in the course, know that they learn differently, and show a positive attitude towards them. Since face-to-face students never have the opportunity to experience being online students, they cannot understand what the latter are experiencing, or their own responsibility for the academic and social integration of their online classmates. Instructors should educate their students on this matter and make sure that they respect and are considerate of their online peers, in order to ensure a positive learning climate for all. As online students in BSC require extra effort compared to face-to-face students, such as the use of microphones and facing the camera to speak or chat with online students during the courses, they may be reluctant to take online students into account (Cunningham, 2014). This feeling may be exacerbated if instructors have to spend time troubleshooting technical issues and end up delaying the start of the course (Wang \& Huang, 2018). On a related note, some instructors pay online students no 
attention and focus only on face-to-face students. Engaging with both online students and face-to-face students in BSC may be difficult (Francescucci \& Foster, 2014). Moreover, online students reported that it is difficult to concentrate during a BSC (Francescucci \& Foster, 2014), because of their inability to hear the questions asked by face-to-face students and to make out the details of the material shared through the interactive whiteboard, for example (Bower et al., 2014). For these reasons, some online students might feel less attended to and less welcome in the course (Hastie et al., 2010) or that their comments are not taken into consideration by face-to-face students.

Online students' attitude and level of technological skill are also key elements in the success of BSC. In terms of their attitudes, some are active students, which breaks the sense of remote participation. However, others may slow down the course by failing to respect speaking rights or by connecting late. At the same time, it is difficult to give online students free access to speaking rights (Wang \& Huang, 2018). They often have to use text to indicate when they want to speak as opposed to being able to raise their hands, and sometimes, they are limited to written participation only. Communication seems to be smoother between face-to-face students as compared to between online and face-to-face students (Bower et al., 2014). Moreover, some face-to-face students feel that faculty spend too much time and effort meeting the technical needs of online students (Szeto, 2014), especially when they do not log on in advance or when they experience technical issues. Online and face-to-face students also reported sound problems and a lack of access to some social cues, such as the body language and nonverbal attitudes of online students (Cunningham, 2014; Wang \& Huang, 2018). In order to give equal opportunity to all participants in course discussions, some structured discussion strategies could be implemented (Wang et al., 2018). Certain tools could also be used to better integrate online students, such as cameras instead of chat, and iPads, each set up for an online student (Bell, Sawaya, \& Cain, 2014).

The results of the study revealed that students' level of technological skill may be a challenge in BSC for online and face-to-face students. Students should know how the platform works in order to be able to interact and work together in real time. If some online students lack technological skills, instructors may focus on these students and spend their time troubleshooting their technical problems. Technology may also be an issue for face-to-face students. They may feel uncomfortable because they have to position themselves in front of a camera or speak into a microphone (Bower et al., 2014, 2015; Cunningham, 2014). It is recommended to invite students to training sessions on the technology tools used in BSC (Bell, Cain, \& Sawaya, 2013; Bell et al., 2014; Bower et al., 2014, 2015; Francescucci \& Foster, 2014; Wang \& Huang, 2018). More broadly, higher education institutions and graduate programs should consider these recommendations and offer introductory sessions on the IT tools and platforms used in BSC for both instructors and students.

\section{Recommendations for effective BSC}

This study opened to several recommendations, which are summarized as follows. First, teaching, learning and assessment strategies should respond to students' needs in BSC. These needs should be identified at the beginning of the BSC so that instructors can adjust to them early in the course. Second, instructors should undergo training in order 
to develop expertise in effective BSC. The fact that they are good instructors in face-toface courses does not mean that they possess the necessary skills to be good instructors in BSC. Several options could be offered to them. Training videos could be provided in this respect. Teaching and learning centers could support instructors in developing their teaching skills. Instructors should also be able to assess their performance in BSC. For example, there could be a video coverage of instructors during their teaching lessons in BSC so that they will have a review of their performance and improve on specific aspects where necessary. Third, in order to better integrate online students in BSC, the use of cameras or iPad, and other alternative techniques such as quizzes or online polls as formative evaluation tools should be mandatory. Some structured discussion strategies could also be implemented to give equal opportunity to all participants in course discussions. Fourth, all students should be trained on effective BSC before the beginning of the course, in order to make sure they respect and are considerate of their peers (online or face-to-face) and that they use IT tools and BSC platforms adequately. Higher education institutions should offer systematically introductory sessions on these tools and platforms.

\section{Conclusion}

The aim of this study was to report on features fostering the academic and social integration of all students in BSC in the MTP, as experienced by online and face-to-face students as well as their instructors. To our knowledge, this is one of a few rare studies conducted on this delivery mode in a university in the province of Quebec, Canada. Indeed, previous studies on BSC were carried out mainly in Australian universities, where this course delivery mode seems to be popular (Bower et al., 2014, 2015; Cunningham, 2014; Hastie et al., 2010), in Chinese universities (Szeto, 2014; Szeto \& Cheng, 2016), and in American universities (Abdelmalak \& Parra, 2016; Bell et al., 2014; Francescucci \& Foster, 2014; Miller, Risser, \& Griffiths, 2013). The results of this study may help higher education institutions to target some relevant interventions or continuing education for instructors as well as resources for instructors and students in BSC. The results of the present study show that the features fostering academic and social integration can be grouped into two themes: first, the appropriateness of pedagogical strategies and BSC for students' training needs, and second, the attitudes, experience and skills of the participants pertaining to online students' inclusion. Within these features, many challenges were identified. These challenges were related to instructors' and teaching assistants' experience with BSC, instructors' and teaching assistants' attitude, instructors' level of technological proficiency, face-to-face students' attitude towards online students, and online students' attitude and technological skills. These challenges have also been highlighted by previous studies and have to be addressed by higher education institutions offering BSC in order to make them more efficient and to ensure the academic and social integration of all students.

\section{Limitations}

The study presents some limitations. Due to the small sample size, the findings of the present study cannot be extended to broader populations or to other contexts. Indeed, these findings may exhibit some bias due to the characteristics of the participants 
interviewed, namely students' and instructors' age and gender, instructors' experience (in terms of number of years of teaching BSC), students' experience (number of BSC enrolled), etc. (see Table 1). Another limitation pertains to the data collected. The features fostering academic and social integration in BSC in the MTP were reported solely according to online and face-to-face students and instructors. Interviews with these participants are part of a larger study where teaching assistants and technicians will be interviewed in the upcoming year in order to obtain their points of view and to clarify the results of the present study and the themes and subthemes that emerged from the data. Moreover, observations of BSC sessions and analyses of pedagogical documents such as course outlines, teaching quality evaluation reports and program evaluation reports will be performed in the short term. This study examined students' and instructors' perceptions only and did not include learning outcomes. Future research could investigate whether the features that foster academic and social integration have an effect on learning outcomes and if these effects are similar for online students and faceto-face students. In this study, online students attended course sessions from multiple sites and students from the Montreal region attended the sessions face-to-face. Thus, students did not have the opportunity to experience course sessions in both the online and face-to-face modes. Did this limit their perceptions and experience to one mode and deprive them of the full experience of attending course sessions online as well as face-to-face? The results of this study should also take this limitation into account.

\section{Acknowledgements}

Not applicable.

\section{Authors' contributions}

$S L$ was the principle researcher in this project. She supervised all the steps of the research: conception and design of the work, analysis and interpretation of data and writing. JM has substantively revised the manuscript. M-EB was the research coordinator of the project. She helped SL in all the steps of the research. GH has revised the manuscript. MC contributed in the analysis and interpretation of data. All authors read and approved the final manuscript.

\section{Funding}

This study has been funded by the Ministère de l'Éducation et de l'Enseignement du Québec and by Canadian Heritage through the Entente Canada-Quebec Program (contracts \#350031081 and \#350033102). The funding body did not have any role in the design of the study and collection, analysis, and interpretation of data and in writing the manuscript.

\section{Availability of data and materials}

The datasets generated during and/or analysed during the current study are available from the corresponding author on reasonable request.

\section{Competing interests}

The authors declare that they have no competing interests.

Received: 8 August 2019 Accepted: 28 January 2020

Published online: 28 February 2020

\section{References}

Abdelmalak, M., \& Parra, J. L. (2016). Expanding learning opportunities for graduate students with HyFlex course design. International Journal of Online Pedagogy and Course Design (IJOPCD), 6(4), 19-37.

Bandura, A. (1997). Self-efficacy: The exercise of control. New York: Freeman.

Bean, J., \& Metzner, B. (1985). A conceptual model of nontraditional undergraduate student attrition. Review of Educational Research, 55, 485-650.

Bell, J., Cain, W., \& Sawaya, S. (2013). Introducing the role of technology navigator in a synchromodal learning environment. In J. Herrington, A. Couros, \& V. Irvine (Eds.), Proceedings of world conference on educational multimedia, hypermedia and telecommunications, (pp. 1629-1634).

Bell, J., Sawaya, S., \& Cain, W. (2014). Synchromodal classes: Designing for shared learning experiences between face-to-face and online students. International Journal of Designs for Learning, 5(1), 68-82.

Benson, V., Anderson, D. and Ooms, A. (2011). Educator's perceptions, attitudes and practices: blended learning in business and management education. Research in Learning Technology, 19(2), 143-154. 
Bernard, R. M., Borokhovski, E., Schmid, R. F., Tamim, R. M., \& Abrami, P. C. (2014). A meta-analysis of blended learning and technology use in higher education: From the general to the applied. Journal of Computing in Higher Education, 26(1), 87-122.

Boelens, R., De Wever, B., \& Voet, M. (2017). Four key challenges to the design of blended learning: A systematic literature review. Educational Research Review, 22, 1-18.

Bower, M., Dalgarno, B., Kennedy, G. E., Lee, M. J., \& Kenney, J. (2015). Design and implementation factors in blended synchronous learning environments: Outcomes from a cross-case analysis. Computers \& Education, 86, 1-17.

Bower, M., Kenney, J., Dalgarno, B., Lee, M. W., \& Kennedy, G. E. (2014). Patterns and principles for blended synchronous learning: Engaging remote and face-to-face learners in rich-media real-time collaborative activities. Australasian Journal of Educational Technology, 30(3), 261-272.

Braun, V., \& Clarke, V. (2006). Using thematic analysis in psychology. Qualitative Research in Psychology, 3(2), 77-101.

Butz, N. T., Stupnisky, R. H., Peterson, E. S., \& Majerus, M. M. (2014). Motivation in synchronous hybrid graduate business programs: A self-determination approach to contrasting online and on-campus students. Journal of Online Learning \& Teaching, 10(2), 211-227.

Collin, S., Calonne, O., Peters, M., Lefrançois, D., \& Saint-Jean, C. (2016). Inclusion d'étudiants à distance dans un cours universitaire en présentiel: Perceptions et adaptations des enseignants et des étudiants dans un dispositif de bimodalité simultanée. In Distances et médiations des savoirs (Distance and mediation of knowledge), (vol. 15).

Cunningham, U. (2014). Teaching the disembodied: Othering and activity systems in a blended synchronous learning situation. International Review of Research in Open and Distance Learning, 15(6), 33-51.

Drysdale, J. S., Graham, C. R., Spring, K. J., \& Halverson, L. R. (2013). An analysis of research trends in dissertations and theses studying blended learning. The Internet and Higher Education, 17, 90-100.

Francescucci, A., \& Foster, M. K. (2014). Virtual interactive real-time instructor-led (VIRI) learning: The case of synchronous blended learning in introductory undergraduate course. Journal of Higher Education Theory \& Practice, 14(2), 36-45.

Halverson, L. R., Graham, C. R., Spring, K. J., Drysdale, J. S., \& Henrie, C. R. (2014). A thematic analysis of the most highly cited scholarship in the first decade of blended learning research. The Internet and Higher Education, 20, 20-34.

Hastie, M., Hung, I. C., Chen, N. S., \& Kinshuk (2010). A blended synchronous learning model for educational international collaboration. Innovations in Education \& Teaching International, 47(1), 9-24.

Hill, P. (2012). Online educational delivery models: A descriptive view. Educause Review, 47(6), 84-97.

Invine, $V$. (2009). The emergence of choice in "multi-access" learning environments: Transferring locus of control of course access to the learner. In G. Siemens, \& C. Fulford (Eds.), Proceedings of World Conference on Educational Multimedia, Hypermedia and Telecommunications 2009, Association for the Advancement of Computing in Education, Chesapeake, VA (2009), pp. 746-752

Irvine, V., Code, J., \& Richards, L. (2013). Realigning higher education for the 21st-century learner through multi-access learning. MERLOT Journal of Online Learning \& Teaching, 9(2), 172-186.

Khechine, H., Lakhal, S., \& Pascot, D. (2014). UTAUT model for blended learning. The role of gender and age in the intention to use webinars. Interdisciplinary Journal of E-Learning and Learning Objects, 10, 33-52

Kyei-Blankson, L., Godwyll, F., \& Nur-Awaleh, M. A. (2014). Innovative blended delivery and learning: Exploring student choice, experience, and level of satisfaction in a hyflex course. International Journal of Innovation and Learning, 16(3), 243-252.

Lakhal, S., Bateman, D., \& Bédard, J. (2017). Blended synchronous delivery modes in graduate programs. Collected Essays on Learning and Teaching, 10(2017), 47-60.

Lakhal, S., \& Khechine, H. (2016). Student intention to use desktop web-conferencing according to course delivery modes in higher education. The International Journal of Management Education, 14(2), 146-160.

Lakhal, S., \& Khechine, H. (2017). Relating personality (big five) to the core constructs of the unified theory of acceptance and use of technology. Journal of Computers in Education, 4(3), 251-282.

Lakhal, S., Khechine, H., \& Pascot, D. (2013). Student behavioural intentions to use desktop video conferencing in a distance course: Integration of autonomy to the UTAUT model. Journal of Computing in Higher Education, 25(2), 93-121.

Lakhal, S., Khechine, H., \& Pascot, D. (2014). Academic students' satisfaction and learning outcomes in a HyFlex course: Do delivery modes matter? In Proceedings of world conference on e-learning in corporate, government, healthcare, and higher education 2014, (pp. 1936-1944).

Lakhal, S. \& Meyer, F. (2019). Blended learning. In Arthur Tatnall (Dir.). Encyclopedia of education and information technologies, Springer International Publishing.

Lane, T. B. (2016). Beyond academic and social integration: Understanding the impact of a STEM enrichment program on the retention and degree attainment of underrepresented students. CBE - Life Sciences Education, 15(3), ar39, 1-13.

Lee, N. E. (2017). The part-time student experience: Its influence on student engagement, perceptions, and retention. Canadian Journal for the Study of Adult Education, 30(1), 1-18.

McGee, P., \& Reis, A. (2012). Blended course design: A synthesis of best practices. Journal of Asynchronous Learning Networks, $16(4), 7-22$

Mihailidis, P. (2014). A tethered generation: Exploring the role of mobile phones in the daily life of young people. Mobile Media \& Communication, 2(1), 58-72.

Miller, J. B., Risser, M. D., \& Griffiths, R. P. (2013). Student choice, instructor flexibility: Moving beyond the blended instructional model. Issues and Trends in Educational Technology, 1(1), 8-24.

Moskal, P., Dziuban, C., \& Hartman, J. (2013). Blended learning: A dangerous idea? The Internet and Higher Education, 18, 15-23.

Paillé, P., \& Mucchielli, A. (2016). L'analyse qualitative en sciences humaines et sociales, (4th ed., ). Paris: Armand Colin.

Park, J. (2007). Factors related to learner dropout in online learning. In F. M. Nafukho, T. H. Chermack, \& C. M. Graham (Eds.), Proceedings of the 2007 Academy of Human Resource Development Annual Conference, (pp. 25-1-25-8). Indianapolis: AHRD.

Park, J. H., \& Choi, H. J. (2009). Factors influencing adult learners' decision to drop out or persist in online learning. Educational Technology and Society, 12(4), 207-217.

Power, T. M. (2008). The emergence of a blended online learning environment. MERLOT Journal of Online Learning and Teaching, 4(4), 503-514.

Quan-Haase, A., Martin, K., \& Schreurs, K. (2016). Interviews with digital seniors: ICT use in the context of everyday life. Information, Communication \& Society, 19(5), 691-707.

Rovai, A. P. (2003). In search of higher persistence rates in distance education online programs. The Internet \& Higher Education, 6(1), 1-16. 
Severiens, S. E., \& Schmidt, H. G. (2009). Academic and social integration and study progress in problem based learning. Higher Education, 58(1), 59-69.

Siemens, G., Gašević, D., \& Dawson, S. (2015). Preparing for the digital university: A review of the history and current state of distance, blended, and online learning. Report Commissioned by the Bill \& Melinda Gates Foundation. Available at: from http://linkresearchlab.org/PreparingDigitalUniversity.pdf.

Skrypnyk, O., Joksimović, S., Kovanović, V., Dawson, S., Gašević, D., \& Siemens, G. (2015). The history and state of blended learning. In: Siemens, G, Gašević, D, Dawson, S (eds), Preparing for the digital university: A review of the history and current state of distance, blended, and online learning, (pp. 55-92). Available at: http://linkresearchlab.org/ PreparingDigitalUniversity.Pdf.

Szeto, E. (2014). Bridging the students' and instructor's experiences: Exploring instructional potential of videoconference in multi-campus universities. Turkish Online Journal of Educational Technology, 13(1), 64-72.

Szeto, E., \& Cheng, A. Y. (2016). Towards a framework of interactions in a blended synchronous learning environment: What effects are there on students' social presence experience? Interactive Learning Environments, 24(3), 487-503.

Thomas, D. R. (2006). A general inductive approach for analyzing qualitative evaluation data. American Journal of Evaluation, 27(2), 237-246.

Tinto, V. (1975). Dropout from higher education: A theoretical synthesis of recent research. Review of Educational Research, $45(1), 89-125$

Tinto, V. (1993). Leaving college: Rethinking the causes and cures of student attrition, (2nd ed., ). Chicago: The University of Chicago Press.

Wang, Q., \& Huang, C. (2018). Pedagogical, social and technical designs of a blended synchronous learning environment. British Journal of Educational Technology, 49(3), 451-462.

Wang, Q., Huang, C., \& Quek, C. L. (2018). Students' perspectives on the design and implementation of a blended synchronous learning environment. Australasian Journal of Educational Technology, 34(1), 1-13.

Yin, R. K. (1994). Case study research: Design and methods, (2nd ed., ). Newbury Park: Sage Publications.

\section{Publisher's Note}

Springer Nature remains neutral with regard to jurisdictional claims in published maps and institutional affiliations.

\section{Submit your manuscript to a SpringerOpen ${ }^{\circ}$ journal and benefit from:}

- Convenient online submission

- Rigorous peer review

- Open access: articles freely available online

- High visibility within the field

- Retaining the copyright to your article

Submit your next manuscript at $\boldsymbol{\nabla}$ springeropen.com 